\section{RE-CREATION OF TRIBALS: DEBT, BONDED SLAVERY AND BONDED PROSTITUTION IN MAHASWETA DEVI'S IMAGINARY MAPS ${ }^{1}$}

\section{Kittiphong Praphan ${ }^{2}$}

\section{บทคัดย่อ}

แรงงานผูกมัดหรือทาสผูกมัด และโสเภณีผูกมัดใน ประเทศอินเดียเป็นมรดกตราบาปที่ถูกทิ้งไว้โดยเจ้า อาณานิคมอังกฤษ ภายใต้ระบบนี้ลูกหนี้ต้องใช้ แรงงานให้กับเจ้าหนี้เพื่อชดใช้หนี้สินที่ตัวเองไม่ อาจชำระได้ Mahasweta Devi ได้นำเสนอ ปรากฏการณ์ทางสังคมนี้ผ่านงานเขียนซึ่งได้วาด ภาพของชนกลุ่มน้อยในเผ่าต่างๆ ที่ตกเป็นเหยื่อของ ระบบนี้ การศึกษาชิ้นนี้สำรวจประเด็นทาสผูกมัด และโสเภณีผูกมัดผ่านการวิเคราะห์สองเรื่องราวใน หนังสือเรื่อง Imaginary Maps ของ Devi โดย งานวรรณกรรมชิ้นนี้บรรยายให้เห็นความแร้นแค้น และความยากลำบากของชุมชนเผ่าต่างๆ ซึ่งเป็นผล

${ }^{1}$ การสร้างชนเผ่าในความหมายใหม่: หนี้สิน ทาสผูกมัด และ โสเภณีผูกมัดในเรื่อง Imaginary Maps ของ Mahasweta Devi

2 (กิตติพงษ์ ประพันธ์) Asst. Prof. Dr. Kittiphong Praphan is a lecturer in the Department of Western Languages and Linguistics at the Faculty of Humanities and Social Sciences, Mahasarakham University, Thailand.
พวงมาจากการแสวงหาประโยชน์จาก ทรัพยากรธรรมชาติและทรัพยากรมนุษย์โดยเจ้า อาณานิคมและนายทุนในพื้นที่ คนกลุ่มนี้แบ่งแยก ตัวเองจากธรรมชาติ โดยเล็งเห็นว่าตนเองไม่ใช่ ส่วนหนึ่งของธรรมชาติ แต่มองตัวเองเป็นผู้ที่ สามารถใช้ธรรมชาติเพื่อสร้างความมั่งคั่งให้กับ ตนเอง เมื่อมองผ่านมุมมองของนิเวศวิทยายุคหลัง อาณานิคมก็จะพบว่า เรื่อง Imaginary Maps ได้ ประณามเจ้าอาณานิคมและนายทุนในพื้นที่ซึ่งได้ ทำลายป่าที่เป็นเสมือนแม่ผู้ให้อาหารและสิ่งจำเป็น ในการดำรงชีพของชนเผ่าเหล่านั้น การทำลายที่ เกิดขึ้นนี้ได้เปลี่ยนแปลงวิถีชีวิตของผู้คนในเผ่า นั้นๆ เงินได้กลายเป็นสิ่งจำเป็นซึ่งทำให้ชนเผ่าต้อง หยิบยืมจากผู้ปล่อยเงินกู้ และเมื่อไม่สามารถชำระ คืนได้พวกเขาต้องกลายเป็นทาสผูกมัดและโสเภณี ผูกมัด ซึ่งถูกเอารัดเอาเปรียบและล่วงละเมิดอย่าง รุนแรง หนังสือเรื่อง Imaginary Maps เป็นสื่อใน การส่งผ่านเสียงที่เล่าเรื่องราวของชนเผ่าเหล่านั้น ซึ่งแสดงให้เห็นถึงความสัมพันธ์ระหว่างลัทธิอาณา นิคม ลัทธิอาณานิคมยุคใหม่ นายทุนในพื้นที่ นิเวศวิทยา และชนเผ่า ธรรมชาติและชนเผ่า เหล่านั้นจากที่เคยมีอิสระ ได้ถูกสร้างขึ้นมาใหม่ให้ เป็นทาสผูกมัดเพื่อประโยชน์ของเจ้าอาณานิคมและ นายทุน
Abstract
Bonded labor or bonded slavery and bonded prostitution in India is a legacy left by British colonialism. Under this 
system, a person has to fall into servitude to whomever he or she has loaned money from with no means of repaying that debt. Mahasweta Devi has raised this social phenomenon in her writing, demonstrating that tribal people are those who have been victimized by this system. This study explores the issue of bonded slavery and bonded prostitution by analyzing two stories from Devi's Imaginary Maps. This literary work depicts the plight of tribal communities as a result of the exploitation of their natural and human resources by colonizers and domestic capitalists. Those exploiters have alienated themselves from nature, considering themselves not to be part of nature but people who can use nature to increase their wealth. The depletion of nature leads to the victimization of the tribal communities. Through the lens of Postcolonial Ecocriticism, Imaginary Maps condemns the colonizers and domestic capitalists for destroying the tribes' forests which serve as a motherly provider for their communities. This destruction forces communities to change their way of life. Money becomes a necessity and causes many tribal members to borrow money from moneylenders. Unable to repay the debt, they become bonded laborers and bonded prostitutes and are seriously exploited and abused. Imaginary Maps serves as a channel through which the tribal voice is heard, depicting the relationship between colonialism, neocolonialism, domestic capitalists, ecology and the tribal communities. From being free subjects, both nature and the tribes are re-created as bonded slaves.

\section{Introduction}

An important activist in India for decades, Mahasweta Devi has dedicated herself to those tribal people who struggle to transcend poverty and suffering that is a result of exploitation by colonialism and capitalism. Through her eloquent, vigorous writing, both fiction and nonfiction, she represents the voice of the oppressed tribal communities who are victimized by the elite in Indian society. As a minority group in India, these people are neglected by the mainstream and the government. Being marginalized and underrepresented, they are severely exploited by so-called capitalists. As she has witnessed and experienced the tribal plight and suffering, Devi has publicized and brought the issues into the social agenda via her several novels, short stories and journal articles. In Imaginary Maps, a collection of three stories depicting the tragic fate of Indian tribal people, Devi illustrates the devastating effects of capitalism which has exploited nature and the tribal communities. This exploitation is a legacy left by British colonialism which oppressed Indian people for hundreds of years. Colonialism gave power to the British colonizers and the indigenous elite by taking advantage of the nation's resources. In spite of independence from British colonization, India has not been totally liberated since the exploitation has emerged in a new form as neocolonialism. This new colonizing system has depleted India's natural resources and enslaved some of the more unfortunate tribal people in bonded labor and bonded prostitution. As described by Pati and Dash (2002: 134), bonded labor refers to 
"the labourer working on annual contracts for repayment on loans taken in cash or kind from the employers. The labourer has no option but to be attached to the employer till the loan is repaid with interest." Under such a contract, the employer has the full right to use the labor of a person to whom he lends money. It is a serious form of exploitation. More terribly, many poor tribal women are bonded into prostitution. Devi's works articulates this poignant social phenomenon. To better understand the exploitative discourse regarding bonded slavery, this paper explores the discourse of the exploitation of nature and human resources through an analysis of two stories in Imaginary Maps: "The Hunt" and "Douloti the Bountiful". This exploration also indicates the relation between the depletion of nature and the victimization of the tribes in India. The major concept employed as the background and tool of the analysis is Postcolonial Ecocriticism. The conclusion is drawn using the concept of ecology through a Marxist lens.

\section{Background}

India is known as one of the countries with the greatest number of different tribes on the planet. Devi (1995: ix) maintains that the "tribal population of India is about one-sixth of the total population of the country. These tribes are divided into many groups. India belonged to these tribes long before the incursion of the Aryan-speaking peoples." This statement suggests that India belongs to tribes who lived harmoniously with nature, which was worshipped as their provider supplying them with food, shelter and other necessities. In fact, the harmonious relationship between the tribes and nature is not specific to the nation of India; it also exists in other parts of the globe. This can be seen, as Merchant (1990: 6) argues, in the Western concept of nature as the motherly provide that has existed since the Chaucerian era, "The Chaucerian and typically Elizabethan view of nature was that of a kindly and caring motherly provider, a manifestation of God who had imprinted a designed, planned order on the world." Although this is a Western view, it is also true for the Indian tribal people, since their lives rely greatly on nature, an important figure whom they treat as a family member.

Devi (1990: x) further states a sense of property did not exist among tribal people; the land, the forests, and the rivers were communal property belonging to everyone. They understood ecology and the environment in a way that outsiders cannot imagine. For example, they begged forgiveness before felling a tree or hunting animals: "You are our friend. I do this because my wife doesn't have any food, my son doesn't have any food and my daughter starves. Before they killed an animal, they used to pray to the animal: the bird, the fish or the deer." The relationship between the Indian tribal people and nature is similar to the relationship between Native Americans and nature. Garrard (2004: 120) describes the relationship between the American native and nature thus, "Since the sixteenth century at least, 'primitive' people have been represented as dwelling in harmony with nature." The ways of life 
of both the tribes in India and native Americans indicate that the concept of native people in relation to nature is universal; they are part of each other. Although these people use nature as a major source of food and other necessities, they respect and treat her as a member of their community. The relationship between native people and nature is also described by Foster (2000: 14), who maintains that humans are part of nature. They are products of environmental evolution and are subject to the natural cycle: "man is affected by the same environmental influences that control the lives of all the many thousands of other species to which he is related by evolutionary ties." The relationship between the Indian tribes and nature attests to the fact that these people truly perceive the significance of nature and understand their own role as subjects within it. Unfortunately, the harmony between the tribes and nature was interrupted by colonizers, who accessed their communities to seek benefit from their resources.

India was colonized and exploited by the British for hundreds of years. Despite the end of colonization in 1947, neocolonialism emerged as a new form of exploitation. This new form of colonialism is operated by Western as well as indigenous capitalists and elites. In theory, neo-colonialism does not refer to the use of military force to rule, control and exploit the colonized. Instead, it is described as the use of economic and political power to seek benefit from less powerful or the poor countries. Young (2001: 45) views neo-colonialism through the lens of economic hegemony and proposes that "Neo-colonialism denotes a continuing economic hegemony that means that the postcolonial state remains in a situation of dependence on its former masters and that the former masters continue to act in a colonist manner towards formerly colonized states." That is, while claiming that it is free, the postcolonial state is in fact not entirely free from its former colonizer. As argued by Mukherjee (2010: 6), Neo-colonialism is as harmful as colonialism, since it systemically uncouples "power from responsibility, to remove or reduce all forms of redress, and to promote the emasculation of all national states and their capacities or even willingness to provide protection to their citizens." In other words, this new form of colonialism, unlike the traditional form, exploits the less powerful country and denies to take accountability for its actions, since the powerful country does not officially rule the less powerful country. In addition, neo-colonialism reduces the power of the government in the poor country, so it is unable to protect its own people. Due to political and economic force, the so-called colonies have to allow the colonizers to exploit their countries, in order that global capitalism may exercise its power. Global capitalism enters poor countries in the form of transnational corporations that make profits through the exploitation of both human and natural resources in those countries. Neo-colonialism is considered to be a development of traditional colonialism, which has destroyed colonized countries to a greater degree, as Loomba (2005: 9) contends, "modern colonialism did more than extract tribute, goods and wealth from the countries that it 
conquered-it restructured the economies of the latter, drawing them into a complex relationship with their own, so that there was a flow of human and natural resources between colonized and colonial countries." The profits from not only natural resources but also human labor are fruitful products enjoyed by colonizers in the age of neocolonialism.

India and its people have suffered from the above catastrophe, as Mukherjee (2010: 6) posits out, this nation is a "site of an intensified exploitation (and as ever, the struggle against this exploitation) by a globalized ruling class." According to Robinson and Harris (2000: 12), a globalized ruling class refers to a "transnational capitalist class" that controls the "transnational state apparatus" and "global decision making." The global ruling class or the transnational capitalist class, with political and economic power derived from neo-colonialism, exploits both the human and natural resources of targeted nations. The poor are the major group victimized by this activity. In addition to economic exploitation by the globalized ruling class, India has also suffered domestic neo-colonialism; that is, a powerful indigenous group dominates and exploits the tribal communities. This powerful indigenous group is associated with the power of neo-colonialism, especially with regard to the British who freed India but left a legacy of their colonialism in the form of power inherited by this indigenous group. Then, they used the power to take advantage of the less powerful group, as argued by Collu (1999: 44), "landowners, moneylenders, and tax collectors, along with the new elite of
English-educated businessmen from Delhi, Bombay, and Calcutta, are the ones who benefit from independence, who inherit commerce, power, and money from the departing British." These groups of people were educated through the British educational system and with their superior knowledge they also inherited power from the British colonizers after independence. With this inherited power, these groups of people increased their wealth through the exploitation of people and nature. Undoubtedly, the tribes are among the largest groups in India, who have been victimized by the above exploiters, who have destroyed their harmony with nature and this will be elaborated in this paper.

\section{Postcolonial Ecocriticism, Development Ideology and Bonded Slavery}

Postcolonial Ecocriticism investigates and critiques detrimental activities instigated by colonialism, focusing on environmental issues including nature, resources, land and the indigenous population. In other words, this school of thought is a conflation of colonialism and ecocriticism which, as stated by Huggan and Tiffin, serves "as a means of challenging continuing imperialist modes of social and environmental dominance" (2010: 2). This lens allows people to understand that, in the postcolonial era, the indigenous people, the natural resources and the environment in postcolonial countries are still used as sources of profit for the former colonizers and also some powerful groups in those countries. With the end of traditional colonialism, this issue is a matter between the more powerful 
countries and the less powerful countries, not the colonizers and the colonized. The new form of domination continues the oppression and exploitation of humans and resources which happened in the colonial era, as Mukherjee puts it, "Both new and old forms [of domination] are marked by the extremes of the rate of accumulation of foreign capital and extraction of resources and cheap labour" (2010: 15). In terms of the exploitation of nature, in particular, Mukherjee argues that it is marked as "environmental subjugation" (51). The mass industrial production hugely destroys the environment while leaving waste and pollution for the indigenous population to suffer. Therefore, it is clear that both humans and nature in the less powerful countries are victimized by exploitative activities to maximize the profit of more powerful countries in the postcolonial era. The indigenous people in the less powerful countries have no rights with respect to environmental justice, which is defined by Adamson, Evans, and Stein (2002: 4) as "the right of all people to share equally in the benefits bestowed by a healthy environment." Instead, the indigenous population is turned into cheap laborers in the mode of production and left to suffer from the detrimental consequences of this production.

The exploitation of resources within less powerful countries by more powerful countries is a critical issue in the age of neo-colonialism. Claiming that poor countries need development and help, the powerful countries enter those nations, offering help in various forms. However, the hidden agenda of this help is to exploit resources in the poor countries under the concept of development ideology. This concept is well described by the relationship between First World countries and Third World countries. According to the concept of neo-colonialism, development ideology is usually employed to seek benefit from poor countries. That is, while claiming to develop the poor countries, the countries that offer help intend to take advantage of their resources. In the same vein as scholars in Postcolonial Studies, Huggan and Tiffin (2010: 28) present a radical view against development ideology stating that it is "little more than a myth propagated by the West that, under the guise assisted modernization, re-establishes the very rift (social, political, economic) between the First and the Third Worlds that it claims to want to heal." The development ideology of neo-colonialism appears in the form of a war against poverty. However, according to Huggan and Tiffin (2010: 29), it "effectively turned poor people into 'objects of knowledge and management', and poor nations into targets for social and political intervention by privileged countries." With such intervention, comes global capitalism, as can be seen in the case of gigantic petroleum corporations, such as Shell and Exxon in Nigeria. As stated by Huggan and Tiffin (2010: 39) these corporations present themselves as benefactors, establishing schools, hospitals and other charity projects, while indulging in an abundance of Nigerian resources. Only international corporations and the Nigerian elite benefit from global capitalism. The poor are still poor and, more, terribly they suffer from the pollution and ecological deterioration as a result of industrial activities brought by 
First World countries. Apart from charity projects, the First World also offers economic assistance to help the poor nations recover from poverty. The concept of development ideology regarding economic assistance is aligned with an argument by Prashad, who maintains that assistance from the First World is always offered with conditions: "Economic aid should be the principle means by which the West maintains its political and economic dynamic in the underdeveloped world" (2008: 9). These detrimental conditions are the results of neocolonialism as well as globalization, which Brennan (2003: 1) views as the invisible hand that "destroys the conditions of life for human beings, among other species." This invisible hand gradually harms the lives of human beings as well as other species and finally leads to their demise. It can be said that global capitalists accept no accountability for their activities in prospering their businesses. In addition, the development ideology, in a way, functions as a shield to protect them from being condemned as international exploiters.

In India, foreign as well as indigenous capitalists pry into the tribal communities with a development ideology initiated by the Indian government. As the tribes are viewed as poor and uncivilized, the government claims that development is imperative for improving their quality of life. Tribal people have to cope with the conflict between the First and the Third Worlds and, at the same time, conflicts between the indigenous mainstream and the tribes. The exploitation of the tribal communities works in the same way as in the case of the First and Third worlds; development ideology is introduced in order to provide space for capitalists to benefit from the resources of the tribal communities. Therefore, the social conflicts, especially the exploitation of the tribes, have not been solved by independence from British colonization. Instead, as Wenzel (1998:128) puts it, social conflicts in Indian society have been exacerbated rather than resolved after independence. To revive the nation after British colonization, a lot of megaprojects such as dam building and road building projects were employed as parts of development ideology, providing opportunities for capitalists to access and exploit the tribes and nature.

The advent of development ideology has caused tribal people in India to suffer deeply; as Devi (1995: x) states, "The government of India has pauperized them." They have become poor because their traditional ways of life have been interfered with by the megaprojects of the development. For example, the dam projects have destroyed immense areas of forest, which before served as the main provider for the tribes. In addition, a large number of tribes have been evicted from the land without reasonable compensation. In his article, Collu condemns the development projects, especially the dam projects, as major culprits for the tribes' plight:

The post-independence thirst for the rapid development and industrialization of India, accompanied by huge public investment in development 
projects such as the BhakraNangal dam in Punjab, the Tungabhadra project in Andra Pradesh, the Hirakud dam in Orissa, the Rihand dam in Uttar Pradesh, and more recently the Narmada Dam project displaced millions of people from their land without offering them adequate compensation for drowned forest and arable land, and contributed to the growing gap between rich and poor and the pauperization of the adivasis. (1999: 48)

The adivasis refers to the tribes or indigenous people in India. As elaborated by Collu, "adi" means "oldest" and "vasi" means "inhabitant." They are considered to be the original inhabitants of India (1999: 45). Without any power to resist, these people have had to give up their homeland for nothing, while only the elite and capitalists have benefitted from those megaprojects. Additionally, as stated by Devi (1995: x) the tribal lands have been illegally sold and transformed into tea gardens or fruit orchards for the rich. Since the tribes have been deprived of the right to dwell on their lands in harmony with nature, a great many of them have fallen into a desperate condition and have been finally trapped by the bonded labor system.

As explained by Devi (1995: xii), bonded labor was introduced by the British; "They created a new class, which took away tribal land and converted the tribes into debt-bonded slaves." The British introduced a monetary system to the tribal communities, while depriving them of their traditional way of life: cultivating, hunting and gathering food in the forests. Money became an important factor in their survival, so they had to borrow from moneylenders when they were in need. Unable to repay the debt, they were forced to become bonded laborers or kamiyasseokias. The term "bonded slaves" is also used because they had to work extremely hard for moneylenders under terrible conditions as if they were slaves. Bonded laborers had to work for moneylenders in order to pay the debt and the interest growing from it. Even after British colonialism, bonded labor was still practiced by the Indian upper classes and capitalists as is evident in Imaginary Maps, in which Devi states that the stories are "still true, and true for the rest of India" (1995: xx). Based on the ideas above, it is clear that bonded labor or bonded slavery is a legacy of British colonialism, which still persists in the age of neo-colonialism. Through the bonded slavery system, it can be said that nature and the poor tribes are imprisoned by a debt that will never be repaid. From free subjects, their identities are re-created as bonded slaves.

\section{Portrayal of Deforestation, Dehumanization and Bonded Slavery in Imaginary Maps}

As portrayed in Devi's Imaginary Maps, the exploitation of nature was instigated by the outsider capitalists, who accessed the tribal communities to gain wealth from deforestation. Both stories investigated in this paper, "The Hunt" and "Douloti the Bountiful," indicate the relationship between the exploitation of nature and the 
victimization of the tribes. As nature, the provider for their community, is destroyed, the tribe members have to become cheap laborers in order to earn income to support their families and are finally trapped into bonded slavery. In "The Hunt," the first story in this book, Devi points out that Western colonizers were among the first groups to access the tribal community and exploit nature through deforestation. This story portrays the life of Mary, the only daughter of an Australian capitalist and a tribal woman in the village of Kuruda. Mary is pursued by an Indian capitalist who is finally killed by Mary herself after his long attempt to sexually exploit her. Devi begins this story by explaining, "Once upon a time whites had timber plantations in Kuruda. They left gradually after Independence" (1995: 2). Dixon, an Australian man in the story, is a white man who benefits from the timber business in the forests of Kuruda, which is land that was previously used by the tribal community. It is his son, who impregnates Mary's mother, who is a tribal woman. $\mathrm{He}$ then sells his house, his forests and everything before leaving her and heading back to Australia. This situation demonstrates how white colonizers are able to access the resources of the tribes and take advantage of them. Similar to the concept of development ideology in Postcolonial Ecocriticism, as discussed earlier, the advent of the colonizers can be read by postcolonial readers as an incident that bestows a new image on the village of Kuruda. These colonizers build new houses, introduce Christianity and offer jobs to the tribes. Even though this activity happens in the colonial era, it is similar to events that occur under development ideology in the age of neo-colonialism, since the assistance comes with the aim of exploiting the tribal communities and their resources through deforestation. In the first section of Imaginary Maps, before the beginning of the story, Devi (1995: xviii) argues that usually the tribes were condemned by the mainstream as an important cause of deforestation because they are the ones hired for the process of felling trees. However, this is not totally accurate since the tribes are forced by poverty to do this job. In spite of their beliefs and their strong bond with the forests, they have no other choice but to cut down trees for money. These people need money to raise and support their families because the sources of food once present in the forests have become depleted. In an interview with tribal members, Devi was told by one of them that they have to do things they do not want to do because they need money to buy food, "I need five rupees a day to buy rice. Ask me to fell a tree, I'll do it unwillingly, but I'll do it. Ask me to chop off a head, I'll do it, because I need five rupees at the end of the day" (1995: xviiixix). Money has become an important factor in the survival of the tribes, since the forests, i.e. their providers, have been destroyed. Therefore, instead of hunting for family provisions, they have to earn money to buy food.

After the departure of the white colonizers, the Indian capitalists, who can be regarded as domestic neo-colonialists, took their place. The Indian capitalists entered the tribes and perpetuated the exploitation of nature via the same means, deforestation. In "The Hunt," Tehsildar, a broker who 
represents Indian capitalists, hires the tribes to fell trees, which he buys from the Prasads at a very cheap price. The capitalist timber business results in a substantial decrease in wild animals, which greatly alters the ways of life of the tribes, especially in terms of hunting in order to support themselves and their families. In fact, the decrease in wild animals happened from the colonial era, when white colonizers started to destroy the forest through the timber business. With the decreasing number of wild animals, it is very difficult for the tribes to hunt. Regarding the changing of the tribal way of life in Kuruda, it is explained in the story, "Once there were animals in the forest, life was wild, the hunt game had meaning. Now the forest is empty, life wasted and drained, the hunt game meaningless" (Devi, 1995: 12). The emptiness in the forests has resulted from the invasion of the capitalists, who have massively destroyed the habitat of the wild animals through commercial deforestation.

To gain a huge profit from the timber business, Tehsildar has to keep the cost as low as possible. In doing so, he buys the Sal trees from the Prasads' land at a very low price; as Mary says to Mr. Prasad: "The bastard tricked you. He took all the profit. Everyone from Tohri to Chipador is laughing" (Devi, 1995: 9). With no means of transportation due to the underdevelopment of the village, Mr. Prasad has no other choice but to accept the very cheap offer from Tehsildar: "With no road, have I the power to sell at profit to anyone?" (Devi 1995: 9). The disconnectedness of the village from the outside world offers opportunities to the capitalist who has more power and methods of transportation to take advantage of the resources. Apart from the very low price of the transaction with the Prasads, Tehsildar further saves costs by hiring very cheap tribal labor: "Others will fell the trees, twelve annas daily for men, eight annas for women for trimming branches and carrying the pieced timber to the trucks" (Devi 1995: 8). The wages that the tribal laborers earn are very low; as Mary states, "Twelve annas and eight annas! No porter carries gentlemen's cases for this price" (Devi 1995: 9). It is clear that the capitalist is exploiting the tribal laborers and the lack of connectivity to the outside world. The exploitation of human resources is a result of the tribes' lack of opportunity; they have no education and are neglected by the government. Most importantly, they are deprived of the customary right to earn a living through the forests. That right disappeared with the animals they used to hunt. Although no one prohibits them from hunting, without animals it is no different from the lack of a right since there is nothing to hunt. This issue is similar to the deprivation of the customary rights of poor people in Europe, as discussed by Foster. He explains the situation of the poor in Europe, who suffered from landlordism:

Traditionally the people had had the right to collect dead wood (wood from dead trees of that had fallen in the forest), which enabled them to heat their homes and cook their food. Landowners, however, increasingly denied the ordinary people the right to collect dead wood along with everything else 
in the forest. Theft of wood, along with poaching and trespassing, were treated with the utmost severity. (2000: 66)

In Europe, the forests were also major providers for poor people but when feudalism claimed rights over the forests, the poor sank deeper into a world of suffering. More terribly, the poor were viewed as a social problem in the eyes of the capitalists and the solution to the problem was "to remove them from the land and to turn them into proletarians" (Foster, 2000: 100). As a result, the poor were placed in the labor force within factories, where they were seriously exploited, while receiving very low wages and living in a desperate condition. The situation in India was no different from the above situation, as it seems that the colonizers brought the same problem to tribal people in this country. In "The Hunt," the capitalist comes to destroy the tribal forests and use their desperate condition to trap them in the same exploitative cycle, turning them into lowwaged laborers. To use Foster's concept of customary rights, the tribes in Kuruda are deprived of the right to use the natural resources of their community, especially the right to use the forest and the right to hunt. Finally, they inevitably become a cheap labor force for capitalists to use in their industry of deforestation. The situations in both Europe and India attest to the fact that the exploitation of nature and the exploitation of human beings are interconnected. The depletion of natural resources results in the plight of the poor who are turned into tools for the capitalist to further exploit nature.
As is evident in Imaginary Maps, apart from low-wage labor which is a consequence of the depletion of nature, bonded labor appears to be a more inhumane system used to exploit the poor tribal communities. Bonded labor, which is also referred to as bonded slavery in Imaginary Maps, works far more effectively than the above case for capitalists to reap benefit from human bodies. Bonded slavery occurs when a person borrows money from a moneylender but cannot repay the amount. He or she must work as a servant to repay the loan and this service seems endless, since the master arbitrarily determines when it should end. Usually, the master will add interest to the initial amount, causing the sum to dramatically increase above the borrower's ability to pay. As explained by Spivak (2012: 105), a "bonded worker offers free work as 'repayment' of a small loan, at extortionate rates of interest, often over more than one generation." That is to say, in most of the cases, borrowers are unable to repay the debt during their lifetime because of the increasing amount. Therefore, their children inherit the debt and work under the same conditions. In a similar way, Finn (2012: 6) states that bonded labor "is usually solidified through a loan, and is embedded intricately in India's socio-economic culture - a culture that is the product of class relations, a colonial history and persistent poverty among many citizens. Also known as debt bondage, bonded labor is a specific form of forced labor in which compulsory servitude is derived from debt." Finn further explains that bonded labor stems from many causes including "an ingrained 
legacy of caste-based discrimination, vast poverty and inequality, an inadequate education system, unjust social relations and the government's unwillingness to alter the status quo" (2012: 7). Based on this argument, bonded labor stems from very complex roots. India is a caste-based society with a huge gap between the rich and the poor and other unjust conditions as elaborated above. These conditions render the poor vulnerable to exploitation. The government's unwillingness to change the situation and solve the problem is partially due to the legacy of colonialism. Many people in government inherited power from the colonizers and benefitted from capitalist activities. The capitalists themselves, as mentioned earlier, also inherited power from the former colonizers. Becoming a bonded laborer is a very tragic story; it seems that this servitude will never end, since it is passed down from parents to children. The children of both the moneylenders and the borrowers have inherited the legacy of bonded slavery.

In Imaginary Maps, the issue of bonded slavery is vigorously articulated via "Douloti the Bountiful." This story portrays the life of Douloti, a tribal girl who has to become a prostitute because of her father's debt. Eventually, she dies from a sexually transmitted disease after being exploited in a whorehouse for a long time. Through the lives of several characters, Devi indicates how bonded slavery works and how much the wretched victims suffer from this inhumane system. The first character to mention is Bono, a member of the Nagesia tribe. He vividly exemplifies the victimization by bonded slavery instigated by Munabar, a rich and powerful man in the village. Under the weight of his debt, Bono falls into servitude to Munabar, who has the right to benefit from everything produced by Bono's labor. Therefore, it seems that a bonded slave or kamiya, has no right to possess any property since it can be snatched by the master; as stated in the story: "First, a Nagesia shouldn't have money. If he does, he shouldn't raise a roof. If you raise a roof, or buy a waterbuffalo, the master will notice. If you buy land, the master will grab it. If you buy cattle, the master will snatch them. If you buy an umbrella for your head, or shoes for your feet, he'll have you tied to the post in the yard and beaten" (Devi 1995: 25). Regarding rights over the bonded slave's property, this subjugation aims at preventing the kamiyas from being able to repay the debt and gain freedom. In Bono's case, after he builds a house from the money he earns from working at a mine, Munabar orders his men to burn it down and severely beats Bono, before forcing him to take 25 rupees and sign a contract with his thumbprint: "Take these twenty-five rupees. You are borrowing this because your house burnt down. From now on you are my bondslave. You will repay by the body's labor" (Devi 1995: 28). In fact, mining in the story is also a form of capitalism which exploits Bono as a laborer and he is further exploited by Munabar, as is evident in the excerpt. This kind of business widens the gap between the rich and the poor; while the mine owner gains more wealth, the laborer sinks deeper into poverty. In addition, the brutal punishment of Bono can be viewed as a warning sign to other kamiyas not to 
initiate any life improvement by owning property. Building a house as a sign of life improvement, in Bono's case, seems to be a threat to Munabar, since it is a sign of the acquisition of freedom, which will lead to the end of bonded slavery. This is the reason why Bono is punished in such a cruel way. He is also forced to take more money and sign a contract with his thumbprint. By doing so, it is almost impossible for him to liberate himself from the increasing debt. Ultimately, to free himself from the imprisonment of bonded slavery, Bono decides to run away.

Another tragic story is portrayed through Ganori, who becomes a kamiya as the result of a three-hundred-rupee debt loaned by Munabar. Treated like an animal by Mubanar, Ganori has to labor under extreme conditions, doing everything that his master orders: "He would slave from morning to night, carry sacks of paddy and wheat on his back...Everything is his job. Crook can't reckon what is and is not his job" (Devi 1995: 20). Ganori is also called Crook because his back has been made crooked by the extreme working conditions that have led to a severe accident: "The scene is delightful. The big officer's Dad, the big landowner of the area, Munabar Singh Chandela has put the axle of the carriage on the shoulders of a human being and is screaming his abuse, shaking his whip in the air. Ganori tries to lift the cart by the strength of his shoulders. Trying, he falls on his face. The axle sits hard on him" (Devi 1995: 34). Ganori is hospitalized; his body is broken so he becomes crooked. His story attests to the animalization of the kamiyas by the master. The working conditions in the above incident are usually reserved for a cow or a horse, not a human being. Obviously, Ganori is dehumanized by Munabar, his master.

Ganori's three-hundred-rupee debt not only enslaves him to the capitalist but also passes on the devastating impact to Douloti, his young daughter. Seeing the potential profitability in Douloti's body, Paramananda, the owner of a whorehouse in the disguise of a saint, offers to liberate Ganori by repaying the debt to Mubanar on the condition that Douloti marries him. Unfortunately, after paying Munabar, instead of marrying her, Paramananda forces her to become a bonded prostitute. The victimization of Douloti is the worst of the worst since she ends up a bonded prostitute in the whorehouse, where her body is exploited until she dies. As stated by Spivak (2012: 112), bonded prostitution is where "the girls and women abducted from bonded labor or kamiya households are thrust together as bodies for absolute sexual and economic exploitation." Douloti's body is commodified by Paramananda as well as his customers; the crime against her body becomes a business transaction conducted by these people. She is presented to a customer as if she were merchandise: "Take a look Latiaji, village girl, Harijan, unmarried and is still a virgin...See today, pay tomorrow" (Devi 1995: 57-58). In this scene, Paramananda sells Douloti's virginity to Latia. Like her father, Douloti is dehumanized by those who exploit her body. Her tragic situation is a consequence of the money her father owes to Munabar. Her suffering is beyond imagination, as her body and dignity are painfully 
destroyed when she is raped by a customer, as described in the story, "his sexual hunger is boundless. Douloti is bloodied many times all through the night" (Devi 1995: 58). Her story emphasizes that the poor tribal members, especially women, are always victimized at an extreme level by the rich and the powerful. Through Douloti's body, Paramananda gains a huge profit from his initial investment and at the same time Latia, as well as other customers, obtain sexual pleasure. Other tribal women in the whorehouse also suffer the same fate, as they are forced to become prostitutes to repay their endless debts. They are objectified and commodified by both the whorehouse owner and the customers. In addition, bonded prostitution is expanded by the demand of the customers who want to enjoy new girls when they are bored with the prostitutes they have already slept with: "Ask him to show me a new harijan girl. I am not having fun with Douloti anymore. These goods are threadbare now" (Devi 1995: 77). The customers' need compels Paramananda to search for new victims and thus the cycle of exploitation and dehumanization continues.

Paramananda perpetuates the bonded slavery in his business by taking all the money made by the prostitutes and lending more money to them for their clothing, cosmetics and other personal necessities: "That's very clever. He'll take the money of the kamiyas' whoring-work, will not give a penny and what he lends will be added to the reckoning of the first loan. That's why your girls dry up like wood" (Devi 1995: 67). That is to say, the prostitutes cannot claim even a small portion of the money they make. In addition, the initial loan is also added to with new loans and unimaginable substantial interest. When Douloti asks for her freedom by pleading that she has made five times the initial loan, Paramananda says, "Yes yes, you've seen the principal. But interest? I bought you clothes, those fifty-two rupees? My body is compassionate, your money has now increased by interest to two and a half thousand. And all accounts are written down" (Devi 1995: 76). With such immense interest, it is beyond doubt that the kamiyas' debts will never be repaid. Douloti will never be liberated because a "three hundred rupee loan becomes infinite in eight years" (Devi 1995: 87). As the title of the story, "Douloti the Bountiful," suggests, Douloti is a bountiful source of wealth for Paramananda and his son, who inherits the prostitution business. She makes money for them by serving as a sex object for Latia, Singh and then other customers, up to 20 men a day. Through bonded prostitution, the three-hundredrupee loan has yielded a fruitful profit of "Over forty thousand" (Devi 1995: 85). Her body is exploited until it dries up and is infected with a malignant sexually transmitted disease. Most terribly, when no longer usable, she is thrown out of the whorehouse and left to die on the journey back to her homeland. The whorehouse refuses to take responsibility for her sick body, as she has now become a burden and not a source of income or profit.

Apart from Douloti's tragic story, the female tribal members' susceptibility to sexual abuse is also addressed in the 
previous story, "The Hunt," although the story ends in a different way. Mary, with her beauty inherited from her father's white blood, is targeted by Tehsildar, who wants her to be his mistress. He has admired her beauty from the first time he saw her but values her as only a sex object: "Wow! What a dish! In these woods?" (Devi 1995: 9). This statement indicates that for the rich, tribal women are valued as only food to gratify their lustful hunger. Although Tehsildar is unsuccessful in pursuing Mary and is murdered at the end of the story, this case proves the potential of tribal women to be sexually victimized by the rich. Unlike Douloti, Mary chooses to react in a violent way and kills Tehsildar in order to protect herself. This revolt against the capitalist power can be deduced as the inheritance of power from her father's white blood, which represents power and superiority, in her body. Her father was a white man who impregnated her mother, a tribal woman. Therefore, she has at least half the blood which represents power. Devi was born and grew up during British colonialism in India, where she experienced the power of the colonizers. Viewed from a postcolonial perspective, Devi created Mary as a hybrid product from the union of a tribal woman and a male colonizer. On the one hand, her vulnerability as a tribal member causes her to be targeted by a capitalist who has inherited power from the colonizers. On the other hand, Devi endows her, as a descendant of a colonizer, with the strength and power to resist and react in a violent way. This is an important reason why her situation is different from that of Douloti. In addition, Mary is not confined to the bonded labor system. Unfortunately,
Douloti has no other choice, since the bonded labor system renders her powerless. Also, Munabar, her exploiter, is a very powerful figure in the area, who cannot be touched by the law. As a result, there is no power to liberate her and she ultimately succumbs to exploitation.

Douloti's story exemplifies the extreme sexual abuse of tribal women in India as a result of the bonded labor system. Those women are unavoidably responsible for the debts initiated by their family members, usually their fathers or husbands. As stated by Devi, either after or before their marriages, they "are taken away when husband or father has borrowed money from the money-lending upper caste. They are taken straight to brothels in the big cities to work out that sum. And the sum is never repaid because the account is calculated on compound interest" (1995: xix). According to this statement, bonded labor in the whorehouse is the matter of the whole nation, not only of Douloti. At the tragic end of Douloti's story, Devi passes on a highly significant message to the reader through the description of Douloti's moment of death. She dies, on Indian Independence Day, on a map of India, which she finds after being driven away from the whorehouse. The description of her dead body lying on the map is heartrending: "Filling the entire Indian peninsula from the oceans to the Himalayas, here lies bonded labor spreadeagled, kamiya-whore Douloti Nagesia's tormented corpse, putrefied with venereal disease, having vomited up all the blood in its desiccated lungs...Douloti is all over India" (Devi 1995: 93). A very important message from this scene is that, although 
India has gained independence from the British colonization, the problem of bonded labor has not been solved. Bonded labor, especially that in the prostitution business, still exists in India; as Devi (1995: xx) states, a story like Douloti's "is still true, and true for the rest of India." Independence confers advantages on only the elite, while the poor tribal people still suffer from transnational and domestic neo-colonialism. Tehsildar in "The Hunt" and Munabar in "Douloti the Bountiful" represent capitalists who employ the power from neo-colonialism to exploit the tribal people in their own country. With tricky business mechanisms and the institutionalization of their power, they reap benefit from both natural and human resources in the tribal communities. While Tehsildar gains his wealth from the timber business, Munabar does so through human trafficking. The social phenomenon presented by these two stories suggests that both natural and human resources in the tribal communities in India are commodified by both colonizers and domestic capitalists.

\section{Conclusion}

The above discussion depicts the correlation between the exploitation of nature and human beings by those who inherited power from the colonizers. The discourse of exploitation in Imaginary Maps can be described by the concept of alienation of nature from man. Marx argues that man treats nature "as his inorganic body, (1) as a direct means of life and (2) as the matter of the object and the tool of his activity. Nature is man's inorganic body, that is to say, nature in so far as it is not the human body" (as quoted in Foster 2000: 72). In other words, man views nature merely as a mode of production. The significance of nature is to be a material in the production process and a supporting factor for human survival. Nature is, thus, important but it is alienated from the human organic body. Further, money is an important impetus for this perception, since monetary value plays a significant role in human society. Wealth is a means of obtaining social status and also a source of power. Therefore, a lot of people struggle to obtain wealth and the alienation of themselves from nature offers them freedom to gain wealth from it, as they view nature as not part of them. The alienation from nature is, as argued by Marx, "expressed through the fetishism of money, which becomes the 'alienated essence': 'Money is the universal and selfconstituted value of all things. It has therefore deprived the entire world - both the world of man and of nature - of its specific value"" (as quoted in Foster 2000: 74-75). Apart from alienating nature from human beings, monetary power also alienates human beings themselves from each other, especially in the case of the capitalists and the laborers. Like nature, human labor is regarded as only a mode of production for capitalists, who increase their wealth while leaving the laborers in a desperate condition. Explaining the life conditions of the laborers in European large towns, Foster (2000: 75) states that the alienation of the workers had "reached the point where light, air, cleanliness, were no longer part of their existence, but rather darkness, polluted air, and raw, untreated sewage constituted their material 
environment." That is to say, workers are deprived of a healthy environment and are forced to live in unclean and unsafe conditions. Because the capitalists alienate both nature and human labor from themselves, they are able to exploit them without any sense of guilt or accountability.

Imaginary Maps indicates that capitalists, as outsiders, enter tribal communities and exploit their nature and human labor, without any sense of caring or accountability for the consequences. They alienate themselves from the tribes and nature and thus believe that they do not belong to the communities. With power, the capitalists can gain as much wealth as they wish and can leave whenever they want, since there is no bond between them, the tribes and nature. The only picture they can imagine, when thinking of nature and the tribes, is a huge pile of money, "In the jungle area everything is profit" (Devi 1995: 65). This is the opposite of the tribes who have a strong bond with nature and land. With this bond, they have no aspiration to move away to other places, except in the case of Bono, the only character in the story who runs away. Instead, other tribal characters simply stay on their land and painfully accept the consequences of the capitalists' devastating activities. When they cannot rely on nature to earn a living, as a result of the destructive business, they are finally victimized, again, by the capitalists. The cycle of this tragic story can be seen through the bonded slavery system, which enslaves the tribes in "Douloti the Bountiful," highlighting the lives of Bono, Ganori, Douloti and others.
Through Imaginary Maps, Devi illustrates that the topographical picture of India is outlined through the plight of the tribal people scattered all over the nation. As suggested by Douloti's death scene, not a single spot in India is free from the oppression and exploitation of the tribes. This is the tragic consequence of colonialism, which encouraged the colonizers to exploit nature and the tribes, and neo-colonialism, which paved the way for particular groups of people to inherit colonial power and use this power for the same purpose. The depletion of the tribal communities' nature leads to bonded slavery which destroys and enslaves the lives of many, including Douloti. It is clear that nature is enslaved by powerful people and this enslavement results in the enslavement of the tribes. The Indian map covered with Douloti's blood signifies that this nation has been constructed from bonded labor, i.e. the tribes' blood and flesh, as well as nature as their home. In spite of their great contribution, they have been marginalized and neglected by the mainstream that aims at maximum profit from their labor and natural resources. In this way, it can be said that the tribes and nature, from being free subjects, have been re-created as bonded slaves for the capitalists to exploit. 


\section{References}

Adamson, Joni, Mei Mei Evans, and Rachel Stein, editors. 2002. The Environmental Justice Reader: Politic, Poetics, \& Pedagogy. Arizona: The University of Arizona Press.

Brennan, Teresa. 2003. Globalization and Its Terrors: Daily Life in the West. London: Routledge.

Collu, Gabrielle. 1999. Adivasis and the Myth of Independence: Mahasweta Devi's "Douloti the Bountiful." Ariel: A Review of International English Literature 30.1: 43-57.

Devi, Mahasweta. 1995. Imaginary Maps, translated by Gayatri Chakravorty Spivak. London: Routledge.

Finn, Devin. 2013. Bonded Labor in India. Human Rights \& Human Welfare: An Online Journal of Academic Literature Review. Web. $<$ http://www.du.edu/korbel/hrhw/ researchdigest/slavery/index.html $>$.

Foster, John Bellamy. 2000. Marx's Ecology: Materialism and Nature. New York: Monthly Review.

Garrard, Greg. 2004. Ecocriticism. London: Routledge.

Huggan, Graham and Helen Tiffin. 2010. Postcolonial Ecocriticism: Literature, Animals, Environment. London: Routledge.
Loomba, Ania. 2005.

Colonialism/Postcolonialism. $2^{\text {nd }}$ Ed. London: Routledge.

Merchant, Carolyn. 1990. The Death of Nature: Women, Ecology and the Scientific Revolution. New York: HarperOne.

Mukherjee, Upamanayu Pablo. 2010. Postcolonial Environments: Nature, Culture and the Contemporary Indian Novel in English. Basingstoke: Palgrave Macmillan.

Pati, Rabindra Nath and Jagannath Dash. 2002. Tribal and Indigenous People of India: Problems and Prospects. New Deli: S.B. Nangia.

Prashad, Vijay. 2007. Darker Nations: A People's History of the Third World. New York: New Press.

Robinson, William I. and Jerry Harris. 2000. Towards a Global Ruling Class? Globalization and the Transnational Capitalist Class. Science \& Society 64.1: 11-54.

Spivak, Gayatri Chakravorty. 1990. Women in Difference: Mahasweta Devi's "Douloti the Bountiful." Cultural Critique. Web. $<$ http://www.jstor.org/stable/ $1354294>$.

Wenzel, Jennifer. 1998. Epic Struggles over India's Forests in Mahasweta Devi's Short Fiction. Alif: Journal of Comparative Poetics 18: 127-58. 
Re-creation of Tribals: Debt, Bonded Slavery and Bonded Prostitution in Mahasweta Devi's Imaginary Maps

Young, Robert J.C. 2001.

Postcolonialism: An Historical

Introduction. Massachusetts:

Blackwell. 